\title{
Study on Numerical Simulation Test of Mining Surface Subsidence Law under Ultrathick Loose Layer
}

\author{
Weiping Shi $\mathbb{D}^{1,2}$ Xiaocheng Qu, ${ }^{1}$ Chuntao Jiang, ${ }^{1}$ and Kaixin $\operatorname{Li} \mathbb{D}^{3}$ \\ ${ }^{1}$ Beijing Anke Industrial Polytron Technologies Inc, Beijing 100083, China \\ ${ }^{2}$ College of Geosciences and Surveying Engineering, China University of Mining and Technology-Beijing, Beijing 100083, China \\ ${ }^{3}$ College of Geodesy and Geomatics, Shandong University of Science and Technology, Qingdao 266590, China
}

Correspondence should be addressed to Weiping Shi; swp1128@163.com

Received 29 December 2020; Revised 27 January 2021; Accepted 24 February 2021; Published 10 May 2021

Academic Editor: Bin Gong

Copyright (c) 2021 Weiping Shi et al. This is an open access article distributed under the Creative Commons Attribution License, which permits unrestricted use, distribution, and reproduction in any medium, provided the original work is properly cited.

In the process of coal mining, the surface subsidence under ultrathick loose layer is abnormal (subsidence coefficient greater than 1.0), which will cause great damage to the surface ecological environment. The fracture propagation and stress evolution of bedrock are of great significance to the prevention of surface subsidence. Taking the 1305 working face of a mine as the background, this paper study the process of crack propagation and stress evolution of bedrock under the influence of ultrathick loose layer by methods of on-site measurement, similar simulation, and numerical simulation. During the research process, the physical model was verified by the measured data. Then, the numerical model was verified by the crack propagation angle and subsidence of bedrock, which were obtained in a similar simulation. Based on the verified numerical model, it was obtained that after the coal seam was mined out, the bedrock above the mined-out area was mainly damaged by tension, while the strata on both sides of the crack expansion angle were mainly damaged by shear and tension. During coal seam mining, for bedrock the process of fracture expansion, subsidence, and stress evolution all could be divided into four stages. This research provides a basis for the control of surface subsidence.

\section{Introduction}

According to the classification method of strata in China, the layers composed of related sediments or accumulations in Quaternary and Neogene, such as alluvium and diluvium, are defined as loose layers [1]. Li [2] pointed out that the thickness of alluvium over $50 \mathrm{~m}$ is called a thick loose layer, and the thickness of alluvium over $100 \mathrm{~m}$ is called ultrathick loose layer. As coal seam mining, the original equilibrium stress state of rock mass and overlying strata around goaf will be destroyed, which will cause collapsing, breaking, and bending of overlying strata in goaf, and when it is transmitted to the surface, it will cause subsidence and damage to the surface.

Relevant scholars have made a series of studies on the movement law of overlying strata for coal seam mining under a thick loose layer. Among them, Du [3] explained the reason of large static pressure, small dynamic pressure, small dynamic load coefficient, and insufficient development of mining fractures in fully mechanized top-coal caving mining under thick loose layer and ultrathin bedrock. Xu et al. [4] obtained the microdeformation law of thick loose layer through field measurement. Wu et al. [5] analyzed the development of water-conducting fracture zone and mining influence range of hard roof under thick loose layer and thin bedrock. Li et al. [6] discussed the load transfer effect and overburden failure characteristics of mining overburden in the working face under thick loose layer and thin bedrock through numerical analysis. Hou [7] applied the key layer theory to thick loose layer and shallow coal seam and concluded that the main problem of roof management in thick loose layer and shallow coal seam is the sliding instability of rock pillars in combined key layers. 
Aiming at the problem of surface subsidence, experts and scholars at home and abroad have obtained the surface subsidence law through methods of field measurement, numerical simulation, and physical simulation. With the continuous updating and upgrading of measuring equipment, the monitoring technology of surface subsidence is gradually improved, and the monitoring efficiency and accuracy are greatly improved. Gueguen et al. [8] and Przylucka et al. [9] used D-lnSAR and PS-lnSAR technology to monitor the surface subsidence of goaf for a long time and pointed out that the subsidence duration is related to the subsidence basin area. Chrzanowsk et al. [10] used GPS to monitor and analyze the law of surface subsidence in mining area. Based on measured data, $\mathrm{Xu}$ et al. [11] obtained the law of the surface dynamic movement parameters in the mining process under a thick loose layer and put forward the prediction formula of the subsidence velocity at any time and any location of the main section. By analyzing observed data, Tan et al. [12] obtained the law of surface movement, as well as various angle parameters and predicted parameters during caving mining. Based on FLAC3D numerical simulation, Liu [13] analyzed the relationship between loose layer thickness and surface movement, as well as subsidence coefficient during deep wide strip mining under ultrathick loose layer. Chen et al. [14] discussed the law of surface movement under the condition of a thick loose layer by UDEC numerical simulation. By physical simulation, Yan et al. [15] revealed the law of surface movement, the mechanism of surrounding rock collapse and failure, and obtained the size of movement strata in different regions.

Based on the above analysis, it is found that in the existing research, there are relatively few studies on the specific analysis of bedrock fracture propagation process and stress evolution, and the analysis of bedrock fracture propagation process and stress evolution is of great significance to the prevention of surface subsidence. Therefore, on the basis of previous studies, this paper studies the crack propagation process and stress evolution of bedrock during coal seam mining. In this article, first, the ground subsidence value under the ultrathick loose layer was obtained through field measurement. Second, according to site geological conditions, a physical model was established, which was verified by the data measured on-site. Third, the movement law of bedrock was analyzed based on physical test, and the crack expansion angle and bedrock subsidence value were obtained in the test. Then, a numerical model consistent with the physical model was established. Through numerical analysis, the crack propagation angle of bedrock and the subsidence value of bedrock were obtained. By comparing with the values obtained from physical tests, the numerical model was verified. Finally, based on the verified numerical model, the process of fracture propagation and stress evolution in bedrock are simulated and analyzed, and the relationships between bedrock movement and fracture propagation, bedrock movement, and stress evolution were established.

\section{Field Condition}

In a coal mine, $3 \#$ coal seam is mined in no. 1305 working face, and the buried depth of the coal seam is $850.7 \mathrm{~m}$, in which the thickness of the loose layer is $724.7 \mathrm{~m}$, and the thickness of bedrock is $126.0 \mathrm{~m}$, which belongs to a typical working face under ultrathick loose layer. 1305 working face has a strike length of $1823 \mathrm{~m}$, a dip length of $223.6 \mathrm{~m}$. The coal seam dip angle is $13^{\circ}$ on average, and the coal seam thickness is $4.04 \mathrm{~m}$ on average. The thickness and mechanical parameters of each stratum above the coal seam were shown in Table 1. After 1305 working face was mined out, the surface subsidence value along strike direction obtained by field measurement is shown in Figure 1. The subsidence of the surface obtained by monitoring is $4.201 \mathrm{~m}$, the bedrock boundary angle at the open-off cut side is $60.3^{\circ}$, and that at the stop line side is $63.8^{\circ}$ (Figure 2).

\section{Similar Simulation Analysis on Bedrock Subsidence under Ultrathick Loose Layer}

According to similarity theory [16-19], combined with the thickness and mechanical parameters of each stratum in Table 1, a physical model of 1305 working face was established. Because the coal seam was buried deeply, only the bedrock was established when the model was set, and the overlying loose layer was applied to the upper surface of the model by means of loads. According to the experiment, the expansion angle of the bedrock fracture on the side of the open-off cut is $65.2^{\circ}$, and that on the side of stop line is $61.4^{\circ}$ (Figure 3 ). This is close to the two boundary angles of the bedrock obtained by monitoring. Thus, the physical model was verified reasonable. On the top of the model, the subsidence curve obtained by a similar simulation is shown in Figure 4. The average subsidence is $3.259 \mathrm{~m}$, which is different from the $4.201 \mathrm{~m}$ obtained by monitoring. This is because the ground subsidence obtained by monitoring includes subsidence amounts of bedrock and ultrathick loose layer, while the subsidence obtained by experiment only includes the subsidence amount of bedrock.

\section{Numerical Simulation Analysis on Bedrock Movement under Ultrathick Loose Layer}

\subsection{Establishment of Numerical Model}

4.1.1. Determination of Strata Parameters. In this section, PFC is selected for simulation analysis. According to related literature [20-24], there are some differences between mechanical parameters input in PFC software and those obtained by numerical calculation. Therefore, a $50 * 100 \mathrm{~mm}$ cylindrical standard specimen is established to check the mechanical parameters of strata. In standard specimen, when the height $L$ and particle radius $R$ satisfy $L / R>80$, the particle size has little influence on the calculation results [25], thus, the particle radius of standard specimen ranges from 0.75 to $1.25 \mathrm{~mm}$, with an average of $1.0 \mathrm{~mm}$.

iThe stope involved in this paper is large and contains a large number of joints. The strata parameters provided in Table 1 are obtained from standard blocks, but standard blocks contain almost no joints. Therefore, first, according to the Hoek-Brown strength criterion [26-29], the parameters of strata containing a large number of joints in the field are 
TABle 1: Parameters of strata.

\begin{tabular}{|c|c|c|c|c|c|c|c|}
\hline $\begin{array}{l}\text { Rock } \\
\text { strata }\end{array}$ & Thickness/m & Density/kg.m & $\begin{array}{c}\text { Uniaxial compressive } \\
\text { strength/MPa }\end{array}$ & $\begin{array}{c}\text { Tensile } \\
\text { strength/MPa }\end{array}$ & $\begin{array}{c}\text { Elasticity } \\
\text { modulus/GPa }\end{array}$ & Cohesion/MPa & $\begin{array}{c}\text { Internal friction } \\
\text { angle } l^{\circ}\end{array}$ \\
\hline $\begin{array}{l}\text { Loose } \\
\text { layer }\end{array}$ & 724.7 & 2210 & & & & & \\
\hline $\begin{array}{l}\text { Fine } \\
\text { sandstone }\end{array}$ & 1.6 & 2340 & 76.8 & 6.9 & 19.6 & 19.28 & 36 \\
\hline Mudstone & 75.09 & 2470 & 40.8 & 5.7 & 6.56 & 11.36 & 30 \\
\hline $\begin{array}{l}\text { Fine } \\
\text { sandstone }\end{array}$ & 3.87 & 2340 & 76.8 & 6.9 & 19.6 & 19.28 & 36 \\
\hline Mudstone & 5.98 & 2470 & 40.8 & 5.7 & 6.56 & 11.36 & 30 \\
\hline $\begin{array}{l}\text { Fine } \\
\text { sandstone }\end{array}$ & 15.15 & 2340 & 76.8 & 6.9 & 19.6 & 19.28 & 36 \\
\hline Mudstone & 8.15 & 2470 & 40.8 & 5.7 & 6.56 & 11.36 & 30 \\
\hline $\begin{array}{l}\text { Fine } \\
\text { sandstone }\end{array}$ & 16.18 & 2340 & 76.8 & 6.9 & 19.6 & 19.28 & 36 \\
\hline Coal 3 & 4.04 & 1350 & 15.8 & 1.8 & 3.52 & 4.82 & 28 \\
\hline Mudstone & 4.01 & 2470 & 40.8 & 5.7 & 6.56 & 11.36 & 30 \\
\hline $\begin{array}{l}\text { Fine } \\
\text { sandstone }\end{array}$ & 10.7 & 2340 & 76.8 & 6.9 & 19.6 & 19.28 & 36 \\
\hline
\end{tabular}

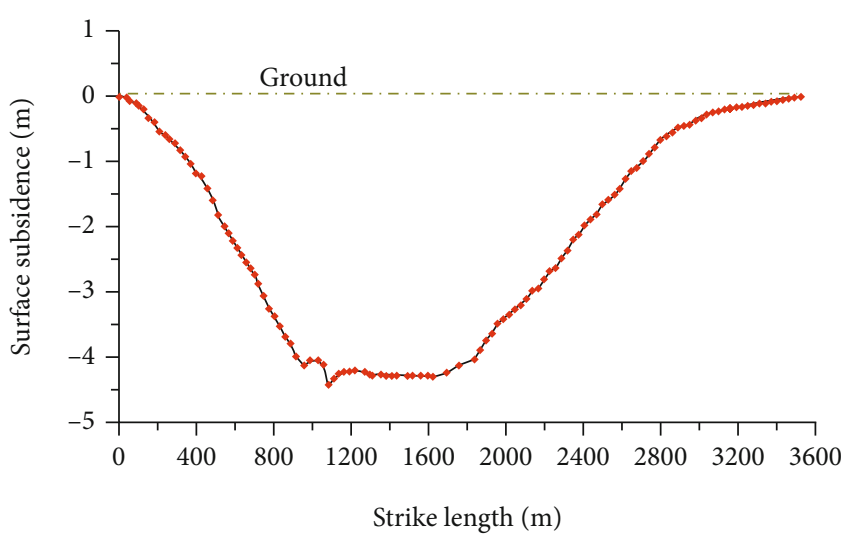

FIGURE 1: Surface subsidence curves along strike length.

nversed [30-33], and then the relevant parameters that need to be input in the numerical simulation are determined by trials and errors. The final input parameters are shown in Table 2.

4.1.2. Determination of Particle Size in Numerical Model. The above mechanical parameters are obtained based on the standard block, and the average particle radius is $1 \mathrm{~mm}$. For bedrock movement numerical simulation, if the model is established with the same particle size as the standard block, the number of particles in the model is large and the calculation time will be too long, so the particle size is enlarged in the numerical model. This section analyzes the influence of particle size on rock mechanics characteristics.

Based on original mechanical parameters of fine sandstone (porosity is 0.05 , ratio of normal stiffness to tangential stiffness is 1.0, and other parameters are shown in Table 1), models of 10 times, 50 times, 100 times, and 500 times stan- dard blocks are established, and the average particle radius is $10 \mathrm{~mm}, 50 \mathrm{~mm}, 100 \mathrm{~mm}$, and $500 \mathrm{~mm}$ in each model, respectively. It is found that uniaxial compressive strength and triaxial compressive strength under $10 \mathrm{MPa}$ confining pressure have little difference as the particle size changes (Figures 5(a) and 5(c)). In the tensile tests, the peak strengths are almost the same (Figure 5(b)), although the strain of each test is different at peak strength location. Therefore, compared with the strength of the standard block, it can be considered that the mechanical parameters of strata are unchanged when large-size particles are used for calculation.

4.1.3. Establishment of Numerical Model. In order to ensure the consistency of the results, the size of the numerical model is consistent with that of the physical model. The size of the model is $300 \mathrm{~m} * 145 \mathrm{~m}$, and the overlying loose layer is applied to the model by external loads. The height of each stratum in the model is shown in Table 1. Considering that the floor under the coal seam has little influence on the results, its mechanical parameters are selected according to the fine sandstone parameters. The values of mechanical parameters of coal seam and all strata are shown in Table 2. In the numerical model, considering the calculation time, the average radius of particles is determined as $600 \mathrm{~mm}$, and there are 35,794 particles in the model. In the model, the contact between particles is chosen as Flatjoint contact. The established model is shown in Figure 6.

4.2. Verification of Numerical Model. In the mining process, the mining method was consistent with the physical model experiment. $40 \mathrm{~m}$ protective coal pillars were set on both sides of the model, so the mining range was $220 \mathrm{~m}$. Monitoring lines of vertical displacement and vertical stress are set at $20 \mathrm{~m}, 40 \mathrm{~m}, 60 \mathrm{~m}, 80 \mathrm{~m}, 100 \mathrm{~m}$, and $126.5 \mathrm{~m}$ locations above the coal seam in the model, which was shown in Figure 7. 


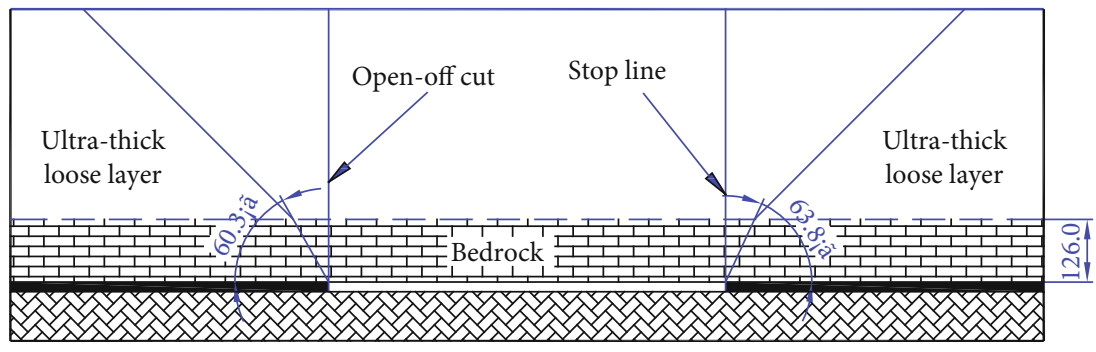

FIGURE 2: Schematic diagram of boundary angle.

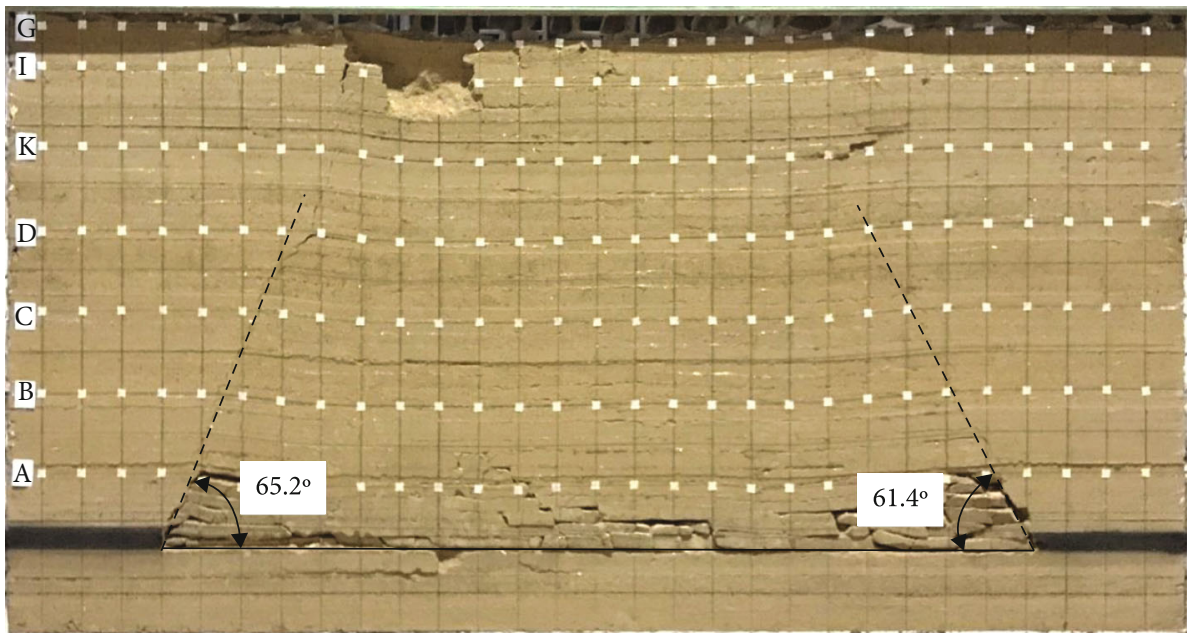

FIGURE 3: Damage of bedrock obtained by physical simulation.

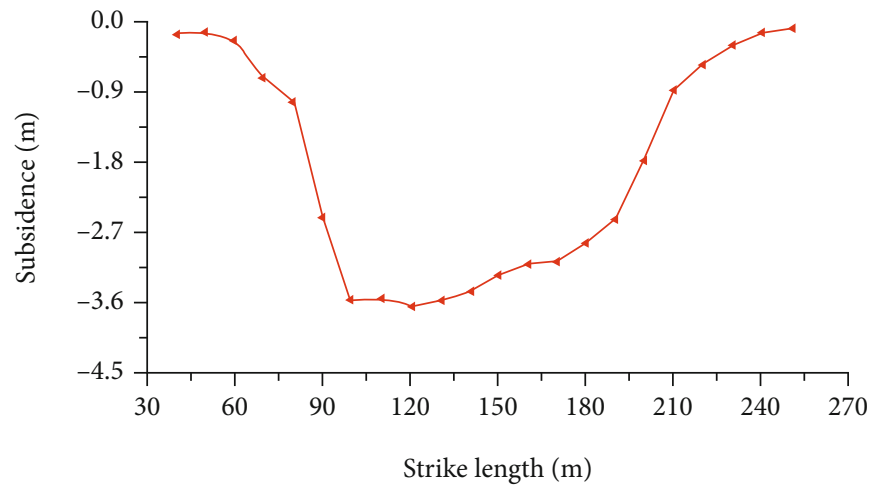

FIgURE 4: Subsidence curve of bedrock obtained by physical simulation.

TABLE 2: Input parameters obtained by trials and errors.

\begin{tabular}{lcccccc}
\hline Name & $\begin{array}{c}\text { Elastic } \\
\text { modulus/GPa }\end{array}$ & $\begin{array}{c}\text { Tensile } \\
\text { strength/MPa }\end{array}$ & $\begin{array}{c}\text { Cohesive } \\
\text { strength/MPa }\end{array}$ & $\begin{array}{c}\text { Internal friction } \\
\text { angle/ }\left({ }^{\circ}\right)\end{array}$ & $\begin{array}{c}\text { Friction } \\
\text { coefficient }\end{array}$ & $\begin{array}{c}\text { Normal (tangential) } \\
\text { stiffness ratio }\end{array}$ \\
\hline $\begin{array}{l}\text { Fine } \\
\text { sandstone }\end{array}$ & 6.2 & 2.0 & 9.55 & 7 & 0.123 & 1.0 \\
Mudstone & 2.5 & 1.65 & 5.05 & 5 & 0.087 & 1.0 \\
Coal seam & 0.9 & 0.51 & 2.45 & 3 & 0.052 & 1.0 \\
\hline
\end{tabular}




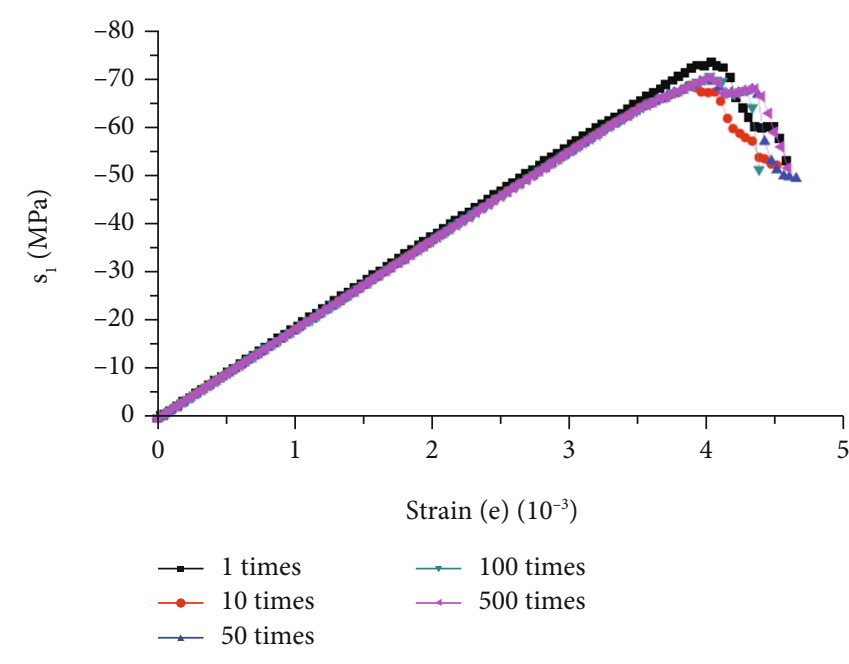

(a) Uniaxial compressive strength

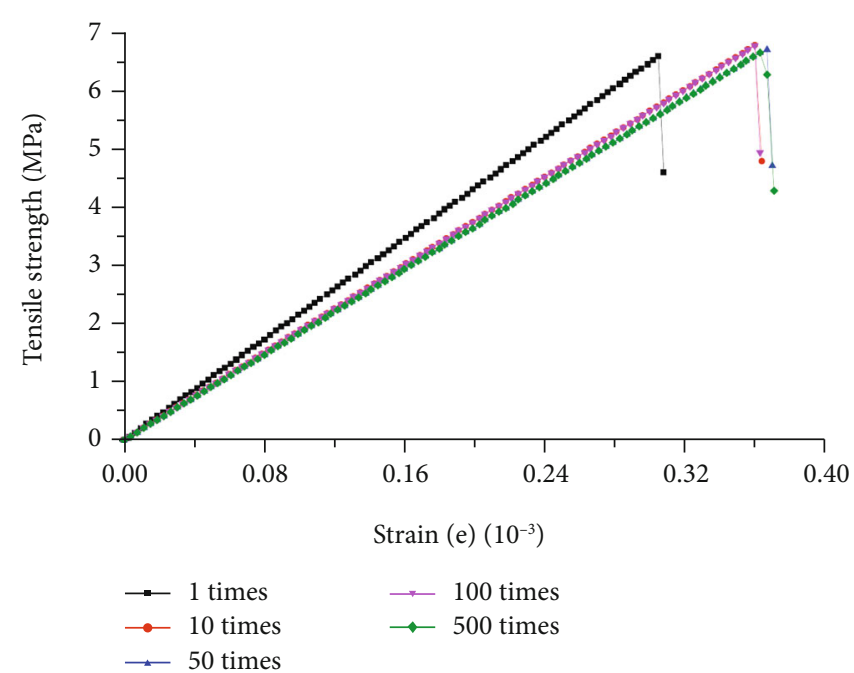

(b) Tensile strength

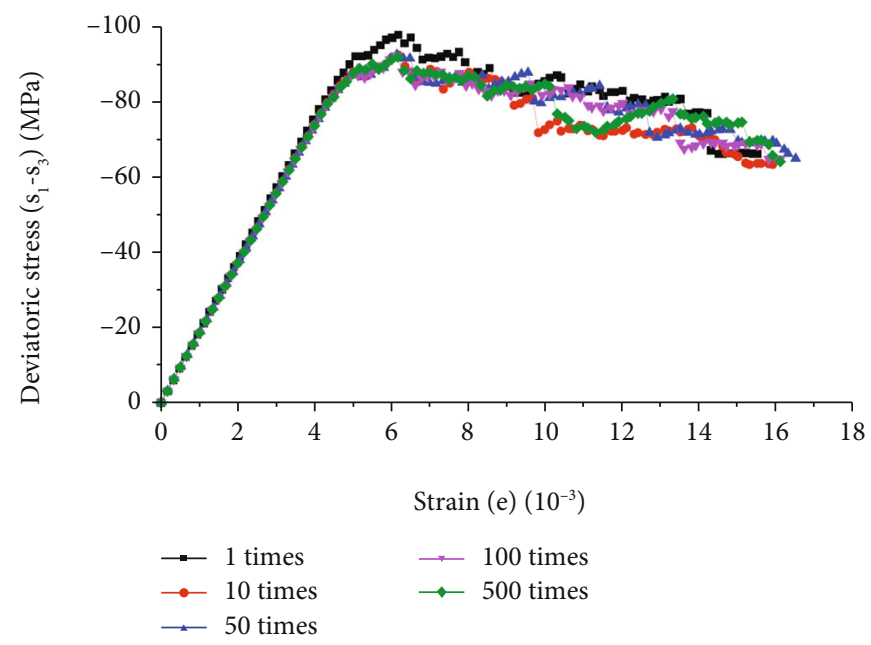

(c) Triaxial compressive strength of $10 \mathrm{MPa}$ confining stress

FIGURE 5: Strength contrast of blocks with different size particles.

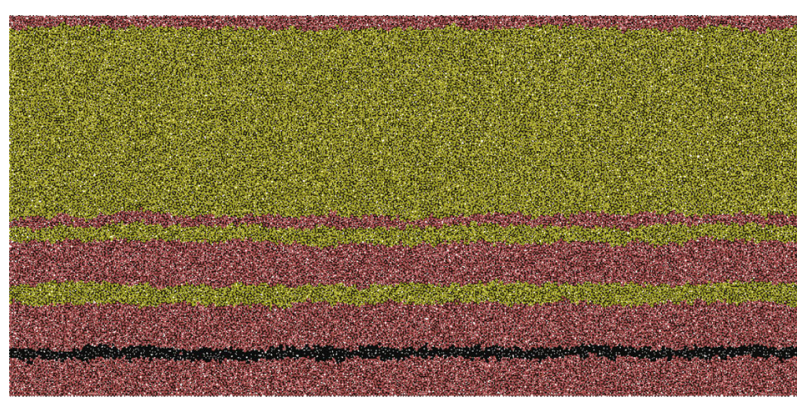

Ball group any

Balls (35794)

Meiceng

Niyan

Xishayan

FIGURE 6: Numerical model on bedrock movement.
After coal seam mining, the fracture of bedrock was shown in Figure 8 , and the subsidence curves of bedrock were shown in Figure 9. In Figure 8, it can be seen that the fracture propagation angle at the open-off cut side was $63.6^{\circ}$, that at the stop line side was $61.1^{\circ}$, and the corresponding values obtained by physical test were $65.2^{\circ}$ and $61.4^{\circ}$, respectively. It can be seen that the fracture morphology of strata in numerical simulation and physical simulation is almost consistent. The comparison of the model top subsidence curve between numerical simulation and similar simulation was shown in Figure 10. In a similar simulation, the average subsidence value in the subsidence basin was $3.259 \mathrm{~m}$, and that value was $2.770 \mathrm{~m}$ in numerical simulation. There was a difference of $0.489 \mathrm{~m}$ between these two results. Compared with the results of similar simulation, the numerical simulation results were reduced by about 15\%. Considering the large size of numerical and physical models, the difference was within the allowable range. Thus, the numerical model, including parameters selection and external force application, was reasonable and could be used in the following analysis. 


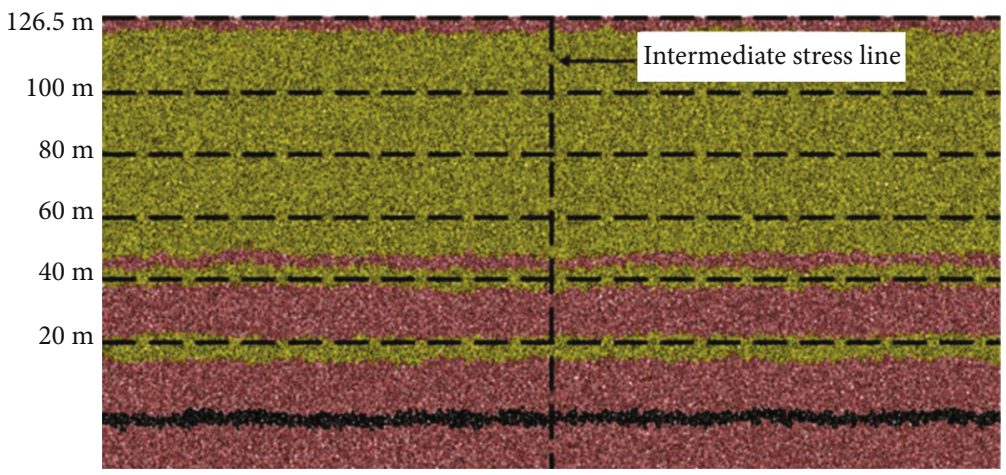

FIGURE 7: Layout of monitoring lines in numerical model.

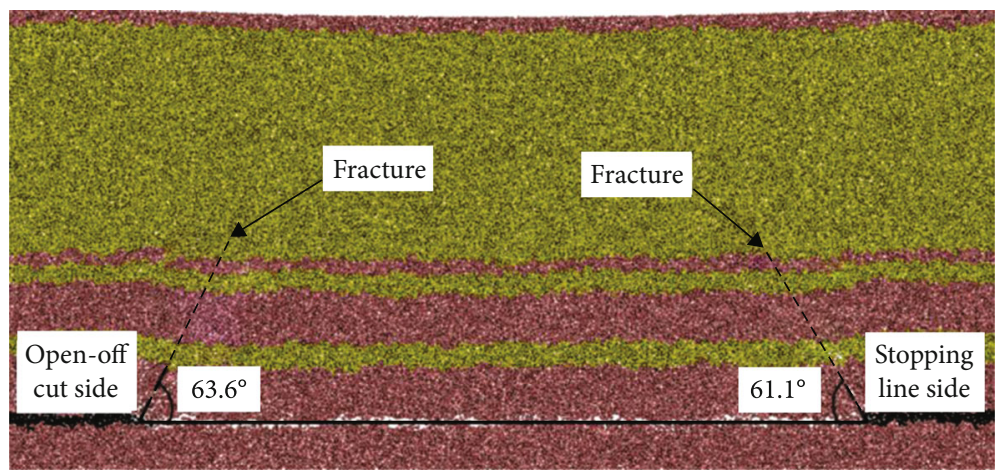

FIGURE 8: Sketch of fracture propagation in model.

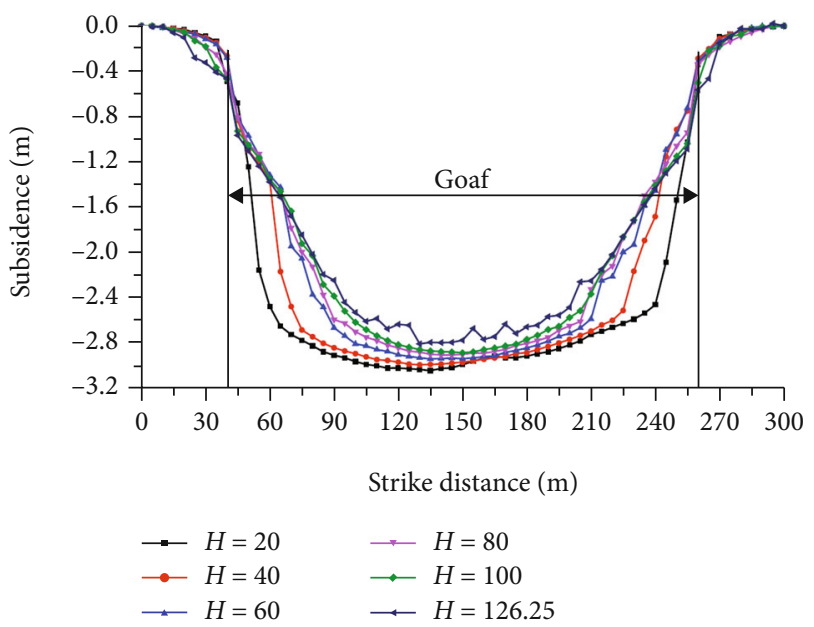

Figure 9: Subsidence curves at different positions above coal seam.

\subsection{Analysis on Bedrock Movement}

4.3.1. Analysis on Fracture Distributions in Bedrock. After mining, the distribution of fractures in bedrock was shown in Figure 11, and the distribution of shear and tensile fractures in bedrock was shown in Figures 12.

In the whole model, there were 21833 fractures, including 8802 shear fractures, accounting for $40.3 \%$ of the total frac-

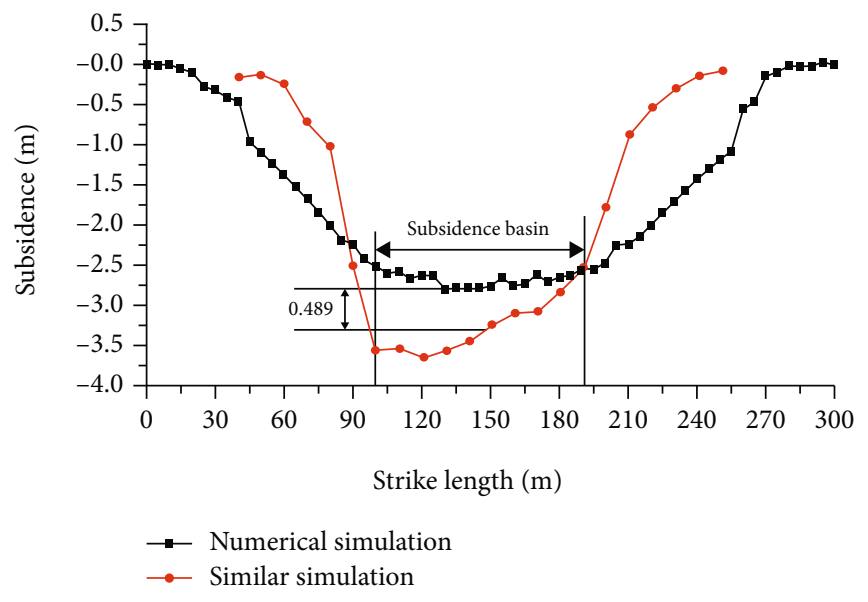

Figure 10: Comparison of numerical simulation and physical simulation results.

tures, mainly distributed on both sides of fractures propagation angle. There are 13031 tensile fractures, accounting for $59.7 \%$ of the total fractures, which are mainly distributed in the strata above the goaf and on both sides of the fractures propagation angle. It can be seen that after coal seam mining, strata above goaf was mainly damaged by tension, while strata on both sides of fracture propagation angle was mainly damaged by shear and tension. 

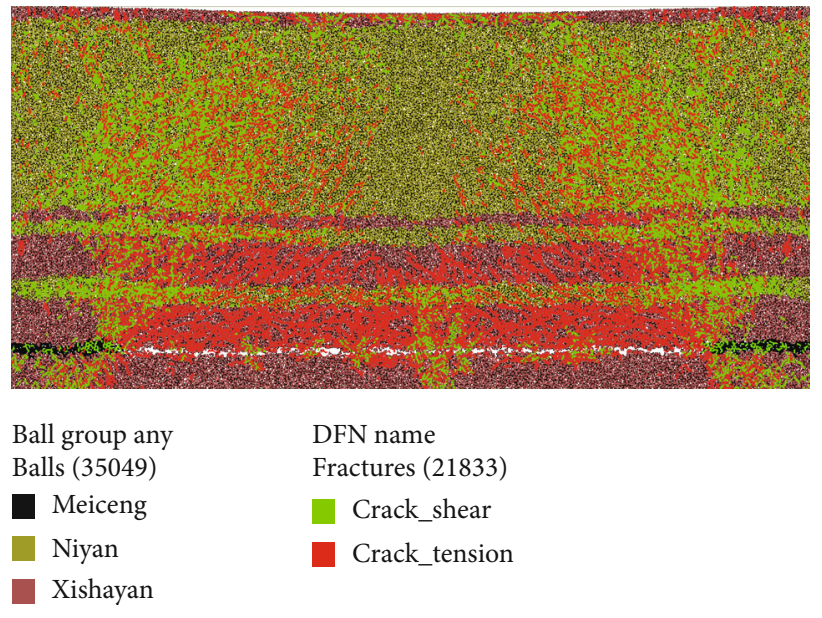

FIGURE 11: Fracture propagation of bedrock in numerical model.

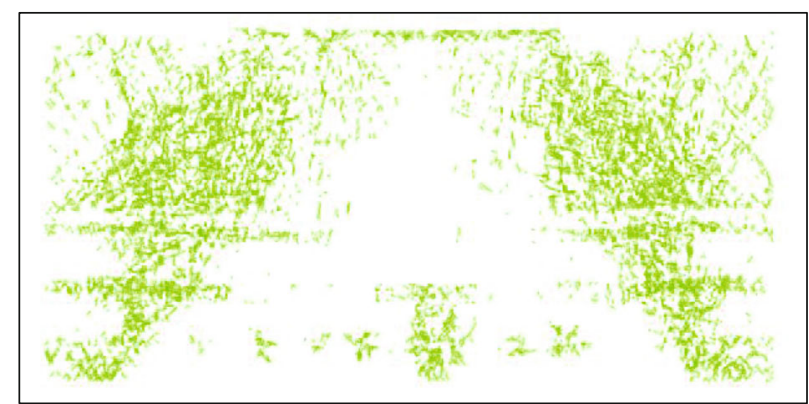

DFN name

Fractures (8802)

Crack_shear

(a) Shear fractures

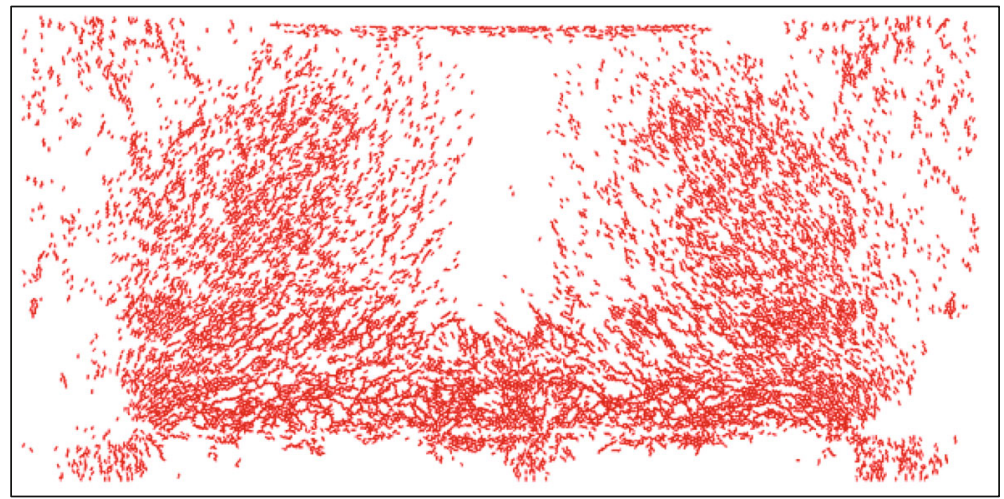

DFN name

Fractures (13031)

Crack_tension

(b) Tension fractures

Figure 12: Distribution of fractures in numerical model.

4.3.2. Analysis on Stress Evolution of Bedrock. The vertical stress evolution curves were shown in Figure 13. It can be seen that after the coal seam was mined, the stress above the goaf was released, and the stress in other positions was low except the abnormal stress in the monitoring line $20 \mathrm{~m}$ in the range of $140 \mathrm{~m}-180 \mathrm{~m}$ from the left boundary of the model. Combined with the fracture propagation figure, it can be seen that the abnormal stress area is a tensile-shear composite failure area, which is located in the center of goaf. It is inferred that the bending and subsidence of bedrock after 


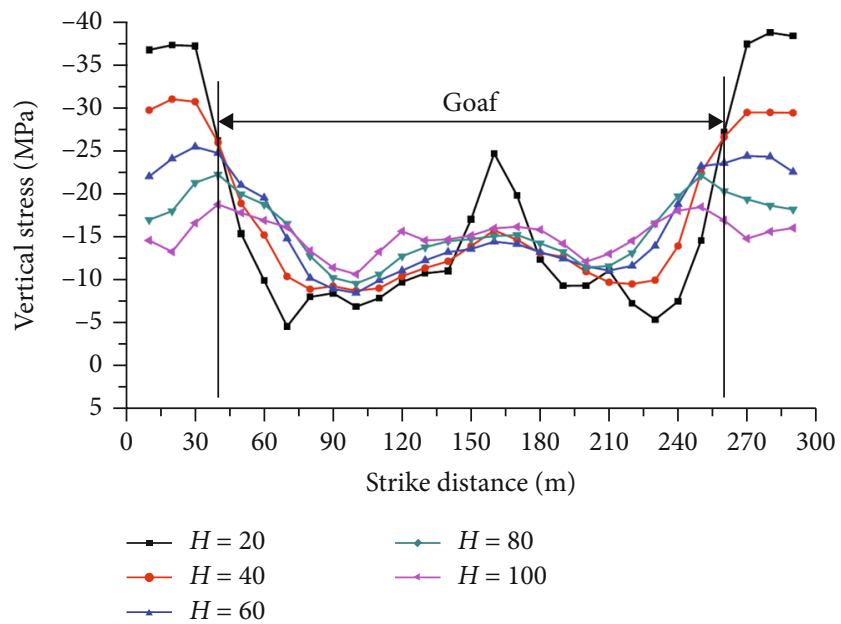

FIgURE 13: Stress evolution curves of bedrock in different positions above coal seam.

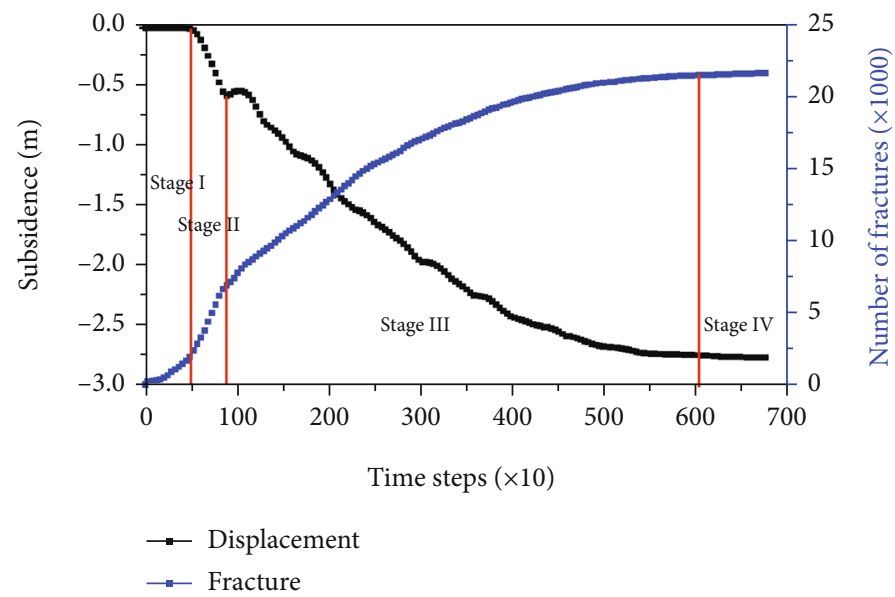

FIGURE 14: Fracture propagation and subsidence of monitoring point in numerical simulation.

coal seam mining leads to tensile failure at this location, the tensile failure area collapses first, and the collapsed strata play a supporting role for the subsequent collapse or bending and subsidence strata, which leads to obvious stress concentration at this position. Combined with displacement evolution curves in Figure 9, it can be seen that in $20 \mathrm{~m}$ monitoring line, the strata displacement in the area $140 \mathrm{~m}-180 \mathrm{~m}$ away from the left boundary is smaller than that in other locations, which further demonstrates the supporting effect of the collapsed strata on the upper strata.

4.3.3. Correlation Analysis between Bedrock Movement and Fracture Propagation. Relationships of number of fractures in model and the subsidence value at the middle of the top of the model, as well as the time step, were shown in Figure 14. It can be seen that the process of fracture propagation and the process of bedrock subsidence could be divided into four stages:

Stage I: the fractures begin to expand, and the subsidence is almost zero. In the range of 0-500 time steps, the fracture propagation curve is in the form of concave, and the fracture propagation rate is gradually accelerated. At this time, because the bedrock movement has not extended to the top of the model, the subsidence of the monitoring point is almost zero.

Stage II: the fracture expanded at a high constant rate, and the monitoring point subsided at a high constant rate. From 500-880 time steps, the fracture expanded at a constant rate (the propagation rate is higher than that in stage I), and the top monitoring point also subsides at a higher rate.

Stage III: the fracture propagation rate and the subsidence rate of the top monitoring point gradually decrease. From 880 to 6000 time steps, the fracture propagation curve was concave upward, and the fracture propagation rate gradually decreased and tended to zero. In this stage, the subsidence curve of the monitoring point was also concave upward after a short stagnation, and the subsidence rate gradually decreased.

Stage IV: the number of fractures almost no longer increased, and the subsidence rate of the top monitoring 


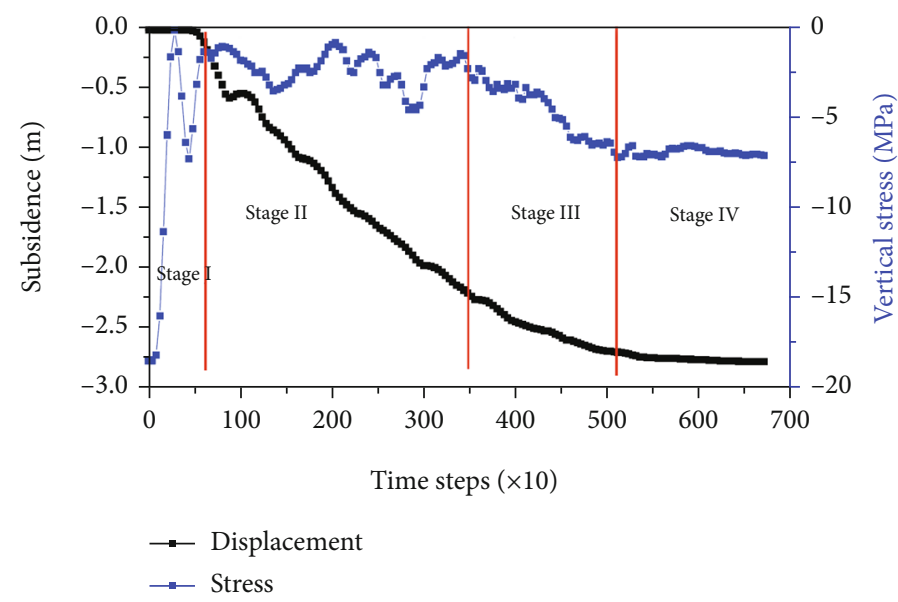

FIGURE 15: Stress evolution of bedrock and subsidence of monitoring point in numerical simulation.

point gradually decreased to zero. From 6000 time steps to the end of simulation, the number of fractures almost stopped increasing, the subsidence rate of the top monitoring point gradually decreased to zero, and the subsidence of the monitoring point increased at a lower rate until the end of simulation.

4.3.4. Correlation Analysis between Bedrock Movement and Stress Evolution. Relationships of subsidence value at the middle of the top of the model, and the vertical stress value at the position $20 \mathrm{~m}$ above the coal seam and $100 \mathrm{~m}$ away from the left boundary of the model, as well as the time step, were shown in Figure 15. It can be seen that the stress evolution curve above the coal seam can be divided into four stages: stage I stress sudden release; stage II lower stress fluctuation; stage III stress gradually increased; stage IV stress tends to be stable.

In stage I, stress in roof suddenly released after coal seam mining, and the stress almost decreased from the original state to zero. And the subsidence of the monitoring point was zero. In stage II, the stress fluctuates in a low state, and at the final of the stage, the stress was still at a low level. In this stage, the subsidence of the monitoring point gradually increased, but the subsidence rate gradually decreased after the initial rapid and constant subsidence. In stage III, the roof stress gradually increased from a lower level to a stable state. In this stage, the subsidence of the monitoring point gradually increased, but the subsidence rate further gradually decreased. In stage IV, the stress was almost constant. In this stage, the subsidence of the monitoring point tended to be stable after a small increase.

Because the stress monitoring point and the subsidence monitoring point were located in different positions of the model, the correlation between them was weak. But when the stress of the roof was zero, the subsidence of the monitoring point was zero. As the collapsed strata were compacted gradually, the stress in roof increased gradually, as well as the subsidence of monitoring point increased gradually. After the stress in roof tended to be stable, the subsidence of the monitoring point no longer increased.

\section{Conclusions}

In view of the importance of fracture propagation and stress evolution of bedrock in preventing surface subsidence, based on a coal mine with a loose layer thickness of $724.7 \mathrm{~m}$, this paper studied the crack propagation and stress evolution of bedrock by field measurement, physical simulation, and numerical simulation. Through analysis, it is concluded that after the coal seam is mined, the strata above the goaf were mainly subjected to tensile failure, while the strata on both sides of the fracture expansion angle were mainly subjected to shear failure and tensile failure. During coal seam mining, the process of fracture expansion, roof subsidence, and stress evolution was obvious in stages. Among them, there was a strong correlation between bedrock fracture expansion and bedrock subsidence. When the bedrock fracture expansion stopped, the bedrock subsidence almost stopped. Because the stress monitoring point and the subsidence monitoring point were located in different positions, the correlation between them was weak. But in general, with the stress in strata above the goaf tending to be stable, the bedrock subsidence no longer increased.

\section{Data Availability}

The data used to support the findings of this study are available from the corresponding author upon request.

\section{Conflicts of Interest}

The authors declare that there is no conflict of interest regarding the publication of this paper.

\section{References}

[1] J. J. Chen, Y. F. Zhou, and W. B. Guo, "Study on the relationship between subsidence coefficient and mining degree under a thick alluvium stratum," Journal of Mining \& Safety Engineering, vol. 29, no. 2, pp. 250-254, 2012.

[2] D. H. Li, Study on Strip Mining Technology under Thick Loose Layer, Science and Technology of China Press, Beijing, 2006. 
[3] F. Du and H. B. Bai, "Mechanism research of overlying strata activity with fully mechanized caving in thin bedrock with thick alluvium," Journal of China Coal Society, vol. 37, no. 7, pp. 1105-1110, 2012.

[4] Y. C. Xu, S. Q. Liu, Y. B. Gao et al., "Study on the internal micro deformation law of thick loose layer," Coal Science and Technology, vol. 42, no. 10, pp. 10-13, 2014.

[5] R. X. Wu, M. L. Wu, J. F. Cao et al., "Electrical monitoring of overburden failure in hard roof working face with thick loose layer and thin bedrock," Coal Science and Technology, vol. 48, no. 1, pp. 239-245, 2020.

[6] J. H. Li, Y. C. Xu, P. Jiang, Y. G. Lian, and Y. Mou, "Study on load transmission characteristics of overburden rock above coal mining face in thin bedrock of super thick unconsolidated stratum," Coal Science and Technology, vol. 45, no. 11, pp. 95-100, 2017.

[7] Z. J. Hou, "Analysis of combinatorial key strata stability in shallow coal seam with thick loose bed," Journal of China Coal Society, vol. 25, no. 2, pp. 127-131, 2000.

[8] Y. Gueguen, B. Deffontaines, B. Fruneau et al., "Monitoring residual mining subsidence of Nord/Pas-de-Calais coal basin from differential and persistent scatterer interferometry (Northern France)," Journal of Applied Geophysics, vol. 69, no. 1, pp. 24-34, 2009.

[9] M. Przylucka, G. Herrera, G. Graniczny, D. Colombo, and M. Béjar-Pizarro, "Combination of conventional and advanced DInSAR to monitor very fast mining subsidence with TerraSAR-X data: Bytom City (Poland)," Remote Sensing, vol. 7, no. 5, pp. 5300-5328, 2015.

[10] A. Chrzanowski, C. Monahan, B. Roulston, and A. SzostakChrzanowski, "Integrated monitoring and modelling of ground subsidence in potash mines," International Journal of Rock Mechanics and Mining Sciences, vol. 34, no. 3-4, pp. 641-647, 1997.

[11] G. S. Xu, D. H. Li, D. F. Hou, and Y. B. Zhang, "Measurement and prediction of the transient surface movement and deformation," Rock and Soil Mechanics, vol. 37, no. 7, pp. 20562062, 2016.

[12] Z. X. Tan, Z. S. Wang, Y. J. Li, X. M. Sun, and K. Z. Deng, "Field research on ground subsidence rules of intensive fullymechanized mining by sublevel caving," Journal of Mining and Safety Engineering, vol. 25, no. 1, pp. 63-66, 2008.

[13] Y. X. Liu, H. Y. Dai, and W. B. Guo, "Surface movement laws of deep wide strip-pillar mining under thick alluvium," Journal of Mining \& Safety Engineering, vol. 26, no. 3, pp. 336-340, 2009.

[14] J. J. Chen, Y. Chen, W. B. Guo, and Y. F. Zou, "Study on surfacemovement law under the condition of thick unconsolidated strata," Coal Science and Technology, vol. 41, no. 11, pp. 95-97, 2013.

[15] Y. G. Yan, H. Y. Dai, Z. W. Wang, S. Q. Jing, and H. Z. Chen, "Ground subsidence zone and surrounding rock failure mechanism due to steep multiple coal seam mining: a case study at Muchenyjian Datai mine," Journal of China University of Mining \& Technology, vol. 42, no. 4, pp. 547-553, 2013.

[16] D. O. Potyondy, "Simulating stress corrosion with a bondedparticle model for rock," International Journal of Rock Mechanics \& Mining Sciences, vol. 44, no. 5, pp. 677-691, 2007.

[17] J. Yoon, "Application of experimental design and optimization to PFC model calibration in uniaxial compression simulation," International Journal of Rock Mechanics \& Mining Sciences, vol. 44, no. 6, pp. 871-889, 2007.
[18] Q. F. Zhao, N. Zhang, and R. Peng, "Similarity simulation experimental study on abrupt collapse of roof separation in large cross-section argillaceous roadway," Journal of Mining \& Safety Engineering, vol. 35, no. 6, pp. 1107-1114, 2018.

[19] Y. J. Chen, C. L. Jiang, and A. J. Wu, "Similar conditions of outburst simulation test for rock cross-cut coal uncovering," Journal of Mining and Safety Engineering, vol. 30, no. 4, pp. 605-609, 2013.

[20] C. Cho, C. D. Martin, and D. C. Sego, "A clumped particle model for rock," International Journal of Rock Mechanics \& Mining Sciences, vol. 44, no. 7, pp. 997-1010, 2007.

[21] H. Hofmann, T. Babadagli, J. S. Yoon, A. Zang, and G. Zimmermann, "A grain based modeling study of mineralogical factors affecting strength, elastic behavior and micro fracture development during compression tests in granites," Engineering Fracture Mechanics, vol. 147, pp. 261-275, 2015.

[22] N. Bahrani, P. K. Kaiser, and B. Valley, "Distinct element method simulation of an analogue for a highly interlocked, non-persistently jointed rockmass," International Journal of Rock Mechanics \& Mining Science, vol. 71, pp. 117-130, 2014.

[23] A. Lisjak and G. Graselli, "A review of discrete modeling techniques for fracturing processes in discontinuous rock masses," Journal of Rock Mechanics and Geotechnical Engineering, vol. 6, no. 4, pp. 301-314, 2014.

[24] B. D. Yang, Y. Jiao, and S. T. Lei, "A study on the effects of microparameters on macroproperties for specimens created by bonded particles," Engineering Computations, vol. 23, no. 6, pp. 607-631, 2006.

[25] D. O. Potyondya and P. A. Cundall, "A bonded-particle model for rock," International Journal of Rock Mechanics \& Mining Sciences, vol. 41, no. 8, pp. 1329-1364, 2004.

[26] E. Hoek and E. T. Brown, "Practical estimates of rock mass strength," International Journal of Rock Mechanics \& Mining Sciences, vol. 34, no. 8, pp. 1165-1186, 1997.

[27] E. Hoek, P. K. Kaiser, and W. F. Bawden, Support of Underground Excavations in Hard Rock, Balkema, Rotterdam, 1995.

[28] M. Cai, P. K. Kaiser, H. Uno, Y. Tasaka, and M. Minami, "Estimation of rock mass deformation modulus and strength of jointed hard rock masses using the GSI system," International Journal of Rock Mechanics \& Mining Sciences, vol. 41, no. 1, pp. 3-19, 2004.

[29] E. Hoek and E. T. Brown, Underground Excavations in Rock, Institution of Mining and Metallurgy, London, 1980.

[30] L. Jing, "A review of techniques, advances and outstanding issues in numerical modelling for rock mechanics and rock engineering," International Journal of Rock Mechanics \& Mining Sciences, vol. 40, no. 3, pp. 283-353, 2003.

[31] D. M. Ivars, M. E. Pierce, C. Darcel et al., “The synthetic rock mass approach for jointed rock mass modelling," International Journal of Rock Mechanics \& Mining Sciences, vol. 48, pp. 219244, 2011.

[32] P. A. Cundall, "Formulation of a three-dimensional distinct element model-part I. A scheme to detect and represent contacts in a system composed of many polyhedral blocks," International Journal of Rock Mechanics \& Mining Sciences, vol. 25, no. 3, pp. 107-116, 1988.

[33] H. Y. Wu, Study on Fracture Characteristics and Core Caking Mechanism of Escabrosa Limestone, Beijing university of science and technology, Beijing, 2018. 